\title{
Review of real-time effective decision support system for water resource management
}

\author{
S. VenkatCharyulu ${ }^{1}$, and Dr. G.K.Viswanadh ${ }^{2}$ \\ ${ }^{1}$ Assistant professor Gokaraju RangaRaju Institute of Engineering \& Technology Hyderabad, India and Research scholar, \\ Department of Civil Engineering, JNTUH, Kukatpally, Hyderabad, India , \\ ${ }^{2}$ Professor of Civil Engineering and Director, UGC-HRDC JNTUH, Kukatpally, Hyderabad, India,
}

\begin{abstract}
The current technologies are predominantly attract the water resource management(WRM); if this water can not adequately utilizing for human activities, then several future problems are happening. Therefore super hydro controlling technology and it's management systems are necessary. In this investigation, various water resource management methodologies, it's merits and demerits are reviewed.The 2R-decision support system(DESS) implementation can change the conventional water management mechanisms, DESS addresses the engineering and non-engineering issues related to WRM system. The global WRM system designs and utilizations are facing many questionaries from experts. In India, there are many WRMs, but these are work for the nation, due to this limitation nations are facing many contemporary issues. Several methods have overcome these limitations but 2R-DESS answering the complete and accurate solutions to WRM. The advanced WRM system and its functionalities are verified on one example with the river basin agencies through DESS adequately. In this research work, for WRM calculating the various measures such as catchment area improvement, supply flow, upper flow, lower flow and acknowledgement of various effecting factors. The designed 2R DESS challenging the present WRM methodologies and results outperforms present technologies.
\end{abstract}

\section{Introduction}

The various water resources are continuously offering the many application related to public, economic, national and environmental issues. The unnecessary usage of the volume of water can disturb the humans lifestyle and living beings. The growth of population, current trending lifestyle and redondant utilization of water resources can create the hazardous and droughts. To change or address this type of problems, there is an advanced solution for WRM. The lack of human power and mobilization can not give the proper solution to the following challenge. There should be a paradigm for resources utilization, thinking of wastewater management and recycling. In recent days many principles and models are dealing with this type of issues, but for future generations an advanced WRM system necessity is there. The decision support system (DESS) is implementing forthe decision-makers during different stages of water resources management. The DESS were addressing industrial and non-engineering issues related to WRM. The DESS can forecast the peak flow of two percent error, and it gives more and more acurate results. In recent past many methodologies designed for WRM, it is identified that such methods are facing managirial type of problems. These limitations and difficulties are briefly explained in the below literature survey. As of now, the different methods dealing the WRM such as 3R principles,closed-loop management, environmental recycling model, one-way WRM and etc. These methods are dealing with the resources Formatting the title, authors. The plan of Johannesburg and his implementation done in 2002, it directly explores the sustainable countries in their devolpments. This theory gives the solution for sustainable WRM, management of recycling and reuse parameters.

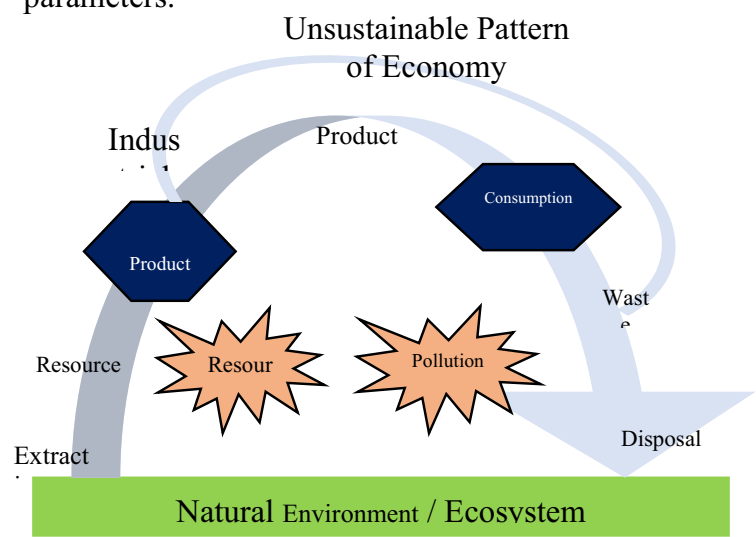


Fig1. WRM system

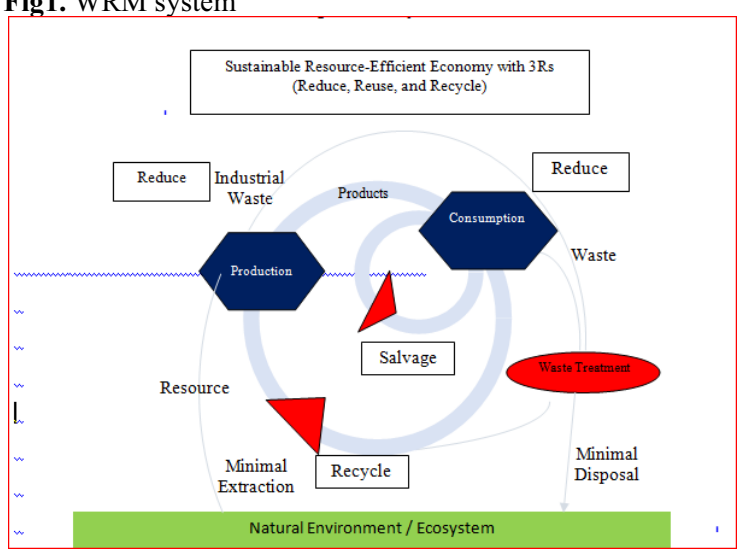

Fig-2 2R-WRM system

The figure1 and figure -2 clearly explain about water resource management system in general arctecture. It is identified that every WRM mainly depending on resources and their proper utilization. The main resoucres of WRM is rains, ground water, rivers and lakes. The leading economy in India majorly depending on water-related applications such as hydropower, industrial utilization, crops, the supply of drinking water and domestic usage. Without any proper drain system at industrials pollute the WRM system. Therefore environmental and health-related problems are happening. The recycling and resources utilization parameters are the key factors of 2R-WRM. The above all discussion gives the usage of a conventional technique for water resource management.

\section{Critical WRM issues for developing}

In this section, various development actions and plans are discussed with roles and their responsibilities. The individuals, communities, business sectors, public sector and private sectors deal the organizational level potentiality of WRM implementation.

Table 1. Role of function

\begin{tabular}{|l|l|l|}
\hline S.No & Governing bodies & \multicolumn{1}{|c|}{ Roles and functionalities } \\
\hline 1 & $\begin{array}{l}\text { Environmental } \\
\text { conditions }\end{array}$ & $\begin{array}{l}\text { To implement any WRM, a } \\
\text { powerful environmental and } \\
\text { eco-friendly platform is } \\
\text { necessary. }\end{array}$ \\
\hline 2 & $\begin{array}{l}\text { Local government } \\
\text { authorities }\end{array}$ & $\begin{array}{l}\text { For the advanced ware } \\
\text { resource management system } \\
\text { necessary to initiate the local } \\
\text { bodies and collaboration with } \\
\text { international partners. This } \\
\text { object can solve the } \\
\text { accommodate issues at the } \\
\text { time of national strategy of } \\
\text { WRM design }\end{array}$ \\
\hline 3 & Land pooling and & In this, abi-lateral and multi- \\
\hline
\end{tabular}

\begin{tabular}{|l|l|l|}
\hline & commodities & $\begin{array}{l}\text { lateral land donor can support } \\
\text { financial issues. For a wide } \\
\text { range of project development, } \\
\text { it is necessary. }\end{array}$ \\
\hline 4 & Private sector & $\begin{array}{l}\text { Different vendors in the } \\
\text { private sector offer project } \\
\text { stability, reusability and } \\
\text { success rate. }\end{array}$ \\
\hline 5 & Informal sectors & $\begin{array}{l}\text { The local sub bodies, NGO's } \\
\text { are supporting the project } \\
\text { always happen when the } \\
\text { collaboration between them is } \\
\text { a success. }\end{array}$ \\
\hline 6 & $\begin{array}{l}\text { Small-medium } \\
\text { enterprises (SME) }\end{array}$ & $\begin{array}{l}\text { The SME's continuously } \\
\text { boosting the project and } \\
\text { adding the improvement with } \\
\text { the help of governments. }\end{array}$ \\
\hline 7 & $\begin{array}{l}\text { Scientific and } \\
\text { academic research }\end{array}$ & $\begin{array}{l}\text { The academic institution and } \\
\text { research groups develop the } \\
\text { project using the transfer of } \\
\text { knowledge between them. The } \\
\text { traing, educating and extension } \\
\text { is the main motto of our } \\
\text { proposed WRM }\end{array}$ \\
\hline
\end{tabular}

\section{The motivation of the work}

In India tropical climates are helping the agriculture and industries, water supply for these sectors can be provided through various resources and it's management. The centralized water projects would take many alternative solutions for the food supply chain in the country. The lack of water resource utilization, uncertainly decreases the countries growth and advancements. Therefore in this research work, decision-support-system based WRM design is implemented.

\subsection{Objectives}

1. An implementation of a roubust water resource management model using 2R-decision- supportsystem in India.

2. The rainfall catchment areas designed using water land interlinking techniquic with help of WRM-DESS.

3. A river basin and river interweaving centralized project design for water resource management system.

4. Drought, floods and drinking water management system using $2 \mathrm{R}$ ranking decision support system.

\section{Literature survey}

The satellites and remote sensing radar observes the water resources for future generations. In this work, various atmospheric and weather monitoring satellites continuously predict the geometrical relation of water at geographical conditions. Along with these functionalities, these satellites observe the rains, 
snowfalls, occasion monitorization and rivers. This satellites fixed in the particular orbit for monitoring the environmental and geographical conditions [1]. The European space agency started a program for water resources in the earth, and these are addressing the critical and specific issues of geographical conditions for WRM[2].

The large scale climatically, environmental problems have prominently interacted with bio-physical monitoring. The tropical climates support the biodiversity project. Thus the global problems have been solved based on human action and their technological WRM projects [3]. The mathematical and physical theories support the water resource management system in a research manner. The significate and sudden raises of environmental conditions seriously produce global issues. The European Union, Netherland states establishing the space and satellite programs for water resource management system. This program providing the crop, water and irrigation projects support. Therefore water resources, weather and environmental conditions are normalized [4]. In extension to classify the requirement of DESS for integrated water resource management (INWRM), different planning's and management are required. The DESS is the advanced and reviewed past study, which can make the WRM efficient. In this research, various significant points are DESS and development of INWRM techniques are investigated [5]. The disaster management and it's supporting systems are clearly explain in [6]. In this work, various research activities related to WRM has been explained based on KAKU K et al. theory. A space related water resource management system can helps the local and global issues for irrigation applications. A decision support human knowledge system design for floods management. The decision management system is an virtual tool it can plan the different real time projects such as forecasting of environment, hydro dynamic applications and flood control system. In this work an advanced DESS implementations are performed an CANADA, Red base in rever, this analysis predict the $2 \%$ peak flow error and revise the operating rules of water management system [7]. Alemu, ET et al [8], in this work various stream predictions and energy forecasting mechanisms are scheduled based on reservoir regulating model. This investigation supports the decision based system with two integrated models, in first step water management and its supply chain mechanisms are analyzed. Coming to second stage DESS provides the time to time updates of reservoir. This resulting that improving the WRM and makes the model in a good manner. Andreu J et al [9] a generalized DESS originally implemented fro decision making association for difficult river basins system. The computer aided design and its modules are makes the system proper design utilizations of water resources.

This research work take reference as segura and tagus river basins as example, this study validate the various river based agencies and its efficient management resources. Arumugam $\mathrm{N}$ et.al [10] the irrigation and water management methodologies are verified on Heih river basin. The DESS is a design which related to integrated water resource problems and its limitations are explore. The main aim of this study to allocate the relationship between supplies and demand. This examination analyzes the various ground evel decision making river basin systems on 40 locations. Costelletti A et al [11] In this integrated WRM systems are recognized and analyzed for planning the feature usages. The European union in $20 \mathrm{k}$ explains about U.n.e.s.c.o countries and their applications. However the implementations of WRM success rate are very high. The control and analytical theory prove that modeling of WRM system takes the decision procedure and identifies the contribution of outstanding work. This work is more conceived the advanced presentation related to constructive discussion.

\section{Key features}

$>$ Contribution of water resource management and its applications in specialist field.

$>$ Compramisation between theory and practical work.

$>$ Integration of various aspects and decision modelling techniques.

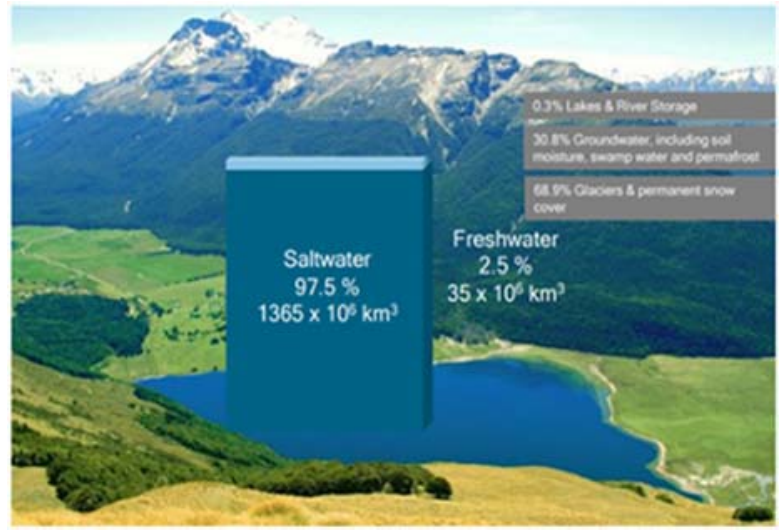

Fig.3. Catchup area estimation(Google source).

various water policies based on different indications they are meteorological, distributive, productive, hydrological, water temperature, river flow and agriculture production [16]. On the other hand various computer aided designs and information technology had increases the real time project assistance. The efficient signal supporting and batch verification is performed on cultivated land. This technique posibily cooperated the alternative development of WRM system [17].

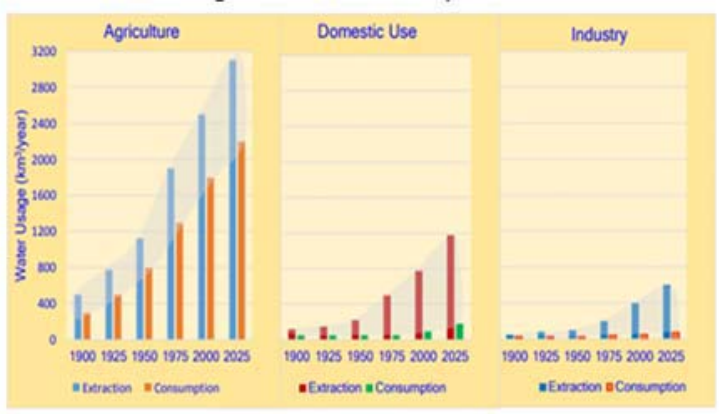


Fig 5: water resource extraction and consumption.

The above fig.5 clearly explains about three types of sectors using water resources; these are nothing but agriculture, domestic and industry. The graphical representations easily figure out the extraction and consumption parameters. Coming to agriculture field at 1990 around $420 \mathrm{~km}^{3}$ water extraction has

Been performed. Coming to consumption $320 \mathrm{~km}^{3}$ water resources are identified. This value raises around $8 \%$ compared to year of 1990, at this domestic usage that values are diminished by around $10 \%$ [18]. Coming to industrial usage water consumption is very less compared to extraction.

\section{Key points about water usage}

$>$ Agriculture sector is an highest usage system it consumes around $70 \%$ of usage.

$>$ Coming to second largest consumers is an industry system, it consumes at $19 \%$ of usage.

$>$ The municipal and drinking water withdrawals are $11 \%$ of usage.

Table 1. Showing references numbers and details.

\begin{tabular}{|c|c|c|}
\hline $\begin{array}{c}\text { Reference } \\
\text { No }\end{array}$ & Technique & $\begin{array}{c}\text { Key points } \\
\text { Reference No }\end{array}$ \\
\hline [19] & $\begin{array}{l}\text { Decision } \\
\text { support } \\
\text { IWRM }\end{array}$ & $\begin{array}{l}\text { In this system around } \\
\text { multiples of } 10 \text { multiples of } \\
\text { river basins are analyzed with } \\
\text { integrated water resource } \\
\text { management. } \\
\text { A prototype of DESS resource } \\
\text { planning's are developed and } \\
\text { effectively analysed with } \\
\text { IDESS.[19] }\end{array}$ \\
\hline [20] & $\begin{array}{c}\text { WRM } \\
\text { managemen } \\
t \text { for } \\
\text { developing } \\
\text { countries. } \\
\text { Learning an } \\
\text { experience } \\
\text { model. }\end{array}$ & $\begin{array}{l}\text { The learning and experience } \\
\text { model designed for water } \\
\text { resource management system, } \\
\text { in the intended users and their } \\
\text { responses are updated with } \\
\text { prority based efforts. }\end{array}$ \\
\hline [21] & $\begin{array}{l}\text { Integrated } \\
\text { advisory } \\
\text { WRM }\end{array}$ & $\begin{array}{l}\text { The lack of integrated tools } \\
\text { are planned and managed } \\
\text { during the water resource } \\
\text { estimation process. } \\
\text { In this work planning and } \\
\text { management of water } \\
\text { resources are designed based } \\
\text { on dish and making process. }\end{array}$ \\
\hline [22] & $\begin{array}{l}\text { Integrated } \\
\text { river basin } \\
\text { managemen } \\
\text { t. }\end{array}$ & $\begin{array}{l}\text { The DESS challenges the } \\
\text { various temporary and spatial } \\
\text { water resources. This is } \\
\text { experience the development } \\
\text { and decision support system } \\
\text { for multi layer structure. } \\
\text { For example pre methods are } \\
\text { handling the DESS, these are } \\
\text { time resolution methods, short } \\
\text { range model and long range } \\
\text { method. These methods are } \\
\text { configure and demanded the }\end{array}$ \\
\hline
\end{tabular}

\begin{tabular}{|c|c|c|}
\hline & & DESS options. \\
\hline [23] & $\begin{array}{l}\text { A generic } \\
\text { and rapid } \\
\text { multi model } \\
\text { assessment. }\end{array}$ & $\begin{array}{l}\text { In this work data interference, } \\
\text { database content, data } \\
\text { visualization and data analysis } \\
\text { are investigated for rivers and } \\
\text { reservoirs. } \\
\text { The reservoirs and river basin } \\
\text { methods are quantify the } \\
\text { losses and routing lacks for } \\
\text { statistical characterization. }\end{array}$ \\
\hline [24] & $\begin{array}{l}\text { Web based } \\
\text { decision } \\
\text { support } \\
\text { system. }\end{array}$ & $\begin{array}{l}\text { The web based DESS } \\
\text { providing the potential } \\
\text { support and safety } \\
\text { measurement for WRM. This } \\
\text { model improves the } 91.82 \% \\
\text { web based improvement has } \\
\text { been attained. }\end{array}$ \\
\hline [25] & $\begin{array}{c}\text { Surface } \\
\text { water } \\
\text { planning in } \\
\text { river basin. }\end{array}$ & $\begin{array}{l}\text { In this research DESS is } \\
\text { effectively improves the } \\
\text { speed, quality and } \\
\text { management of water resource } \\
\text { management system. } \\
\text { The Chicago river basin has } \\
\text { selected as example of water } \\
\text { resource management system } \\
\text { using DESS. }\end{array}$ \\
\hline
\end{tabular}

The above literature survey concentrates the various methods effecting the water resource management and recognizes the solution for limitations. This study improves the feature coming water resource management system with advanced controlling techniques[26][27].

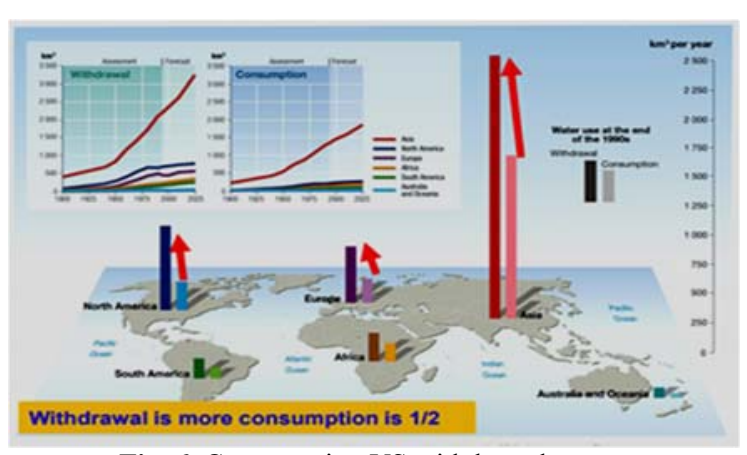

Fig. 6. Consumption VS withdrawal

The figure 6 clearly explains about various water resources withdrawal and consumption in various continents. The selected continents are North America, sourth America, yurup, Africa, Asia and Australia. The observation of this theory explains about withdrawal percentage is $50 \%$ more compared to consumption[2829]. Therefore for feature WRM system design advanced methods to balance the withdrawal and consumption [30].

The above figure7. clearly explains about feature design flow chart of DESS mechanism. In this an integrated compure aidded software designed and gives the assistance for resource planning. This flow chart reduces the risk factors facing by various supply water mechanism. To estimate average rainfall, river basin, sub basin strategies are estimated with above flow diagram[31[32]. This system decrease in the risk factor and gives the reasonable solutions for water supply 
system management. The above flow chart resulting that the water shortage and its impact parameters are analysed easily. This mechanism clearly estimating the intake, withdrawal measures, extraction and conventional operations with more improvement i.e. $3.7 \%, 0.7 \%, 4.4 \%$ and $7 \%$ respectively[33][34].

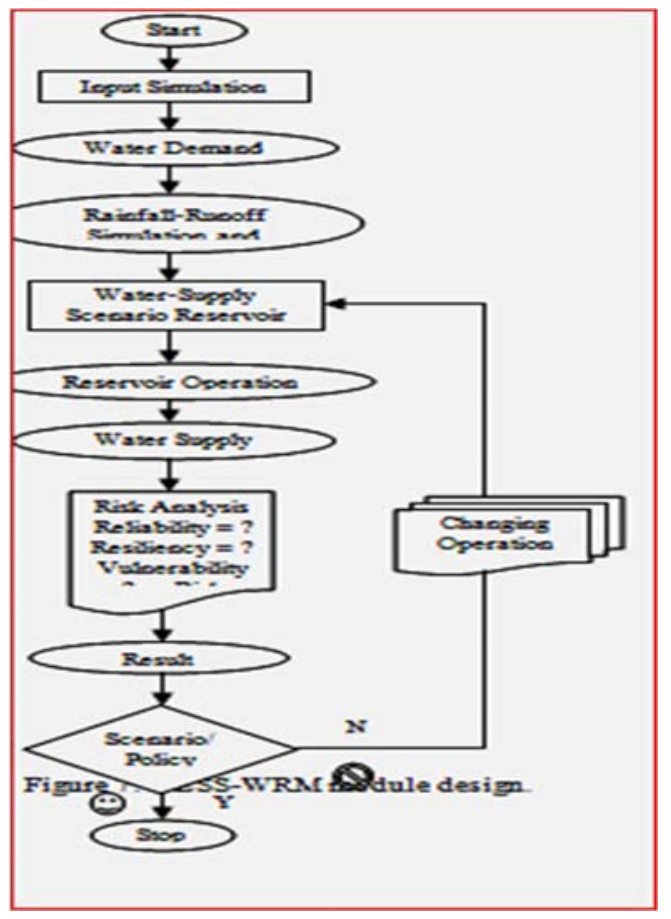

Fig.7. DESS-WRM module design

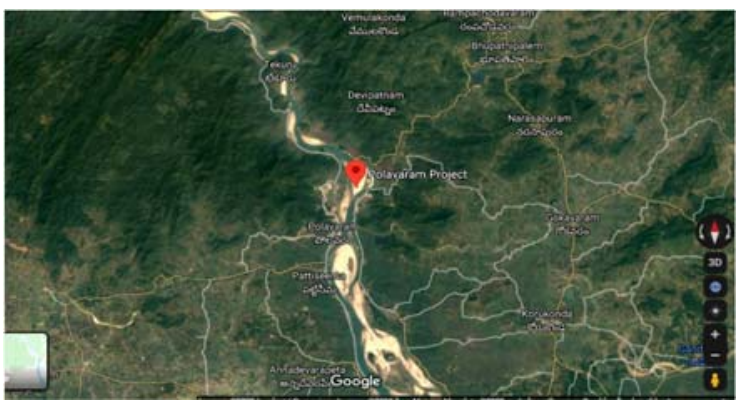

Fig. 8. a) General project

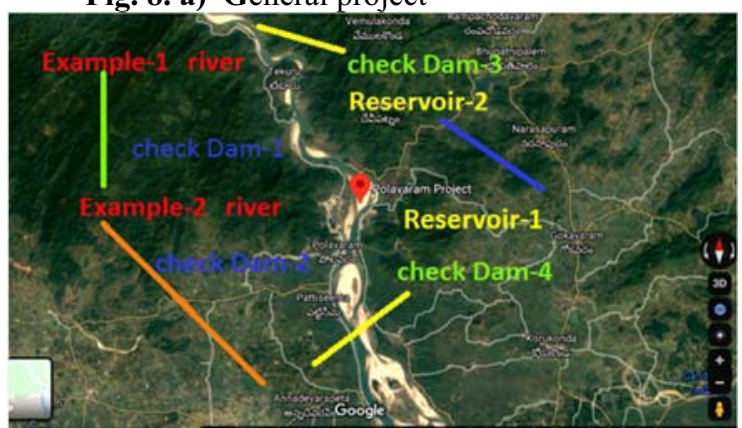

Fig. 8 b). 2R DESS WRM hypothetical example

In this work the figures 8a) and figure 8b) clearly explains about reservoir, check dam and catch up area maintenance for 2R-DESS. The WRM system is designed with the help of following techniques to improve the resources and withdrawal management easily [35]. The proposed decision support systems are planned with 2R-IWRM process, therefore the proposed objectives are successfully attains the expected results. The participatory, institutional aspects and long term sustainability has been achieved.

\section{Problem statement}

In India many water resources are present; these are utilized for agriculture, domestic, industrial and hydro power generations. If these water resources are do not properly managed by river basin system and check dams then automatically floods and droughts have been happening. More over environmental conditions and geographical resources are control the humans and living beings. The agriculture $57 \%$, industrial $16 \%$ and domestic purpose $27 \%$ water resources are necessary. Therefore without proper water resource management system this supply chain has been broken and many problems are creating. So, in this research work a well planned decision support system based WRM has been implementing.

\section{Conclusion}

The DESS technique gives the great potential services for WRM at river basins and check dams. The entire proposed design is simulated on water resource management tool with advanced technique. The proposed 2R-DESS gives the solution for risk management, evaluated management and alternative WRM strategy. In feature 2R-DESS technique with adaptive models enhance the performance measures such as peak flow, upper flow and lower flow parameters. This proposed design improves the WRM at risk facing and critical hydrologic conditions. in feature work we are implementing the objectives which are defined in the above sections.

\section{References}

1. K.H. Szekielda, Satellite monitoring of the earth, Book chapters. Xiv, 326 p, [8] p. of plates ill. (some col.); $26 \mathrm{~cm}(1988)$

2. Y.L Desnos, Borgeaud M, Doherty M, Rast M and Liebig V “The European Space Agency's Earth Observation Program IEEE Geosciences and Remote Sensing" Magazine.

3. J. Aschbacher Earth Observations and Their Impact on Society and Policy (Singapore: Springer) ESA's Earth Observation Strategy and Copernicus Satellite

4. F.J Hawkins 1974 Introduction to the Copernicus satellite - Proceedings of the Royal Society of London A. Mathematical and Physical Sciences (2017)

5. D. NOHARA, GOURBESVILLE, P. \& M A, Q. Towards Development of Effective Decision Support Systems for Integrated Water Resources Planning and Management. Kyoto University Disaster Prevention Institute Annual 
Report. $\mathrm{B}=$ Disaster Prevention Research Institute Annuals.B, 61(B), 702-710, (2018)

6. K. Kaku and Held A Sentinel Asia A spacebased disaster management support system in the Asia-Pacific region International Journal of Disaster Risk Reduction, (2013)

7. References Ahmad, S. and Simonovic, S.P. An intelligent decision support system for management of floods, Water Resources Management, Vol.20, pp.391-410. (2006)

8. E T Alemu, , Palmer, R.N., Polebitski, A.and Meaker, B.,Decision support system for optimizing reservoir operation using ensemble stream flow predictions, Journal of Water Resources Planning and Management, Vol.137, No.1, pp.72-82., (2010)

9. J.Andreu, Capilla, J.and Sanchis, E. (AQUATOOL, a generalized decision-support system for water-resources planning and operational management, Journal of Hydrology, Vol.177, pp.269-291. (1996)

10. N.Arumugam,. and Moha, S. Integrated decision support system for tank irrigation system operation, Journal of Water Resources Planning and Management, Vol.123, No.5, pp.266-273,(1997)

11. A.Castelletti, and Soncini-Sessa, R. A participatory and integrated planning procedure for decision making in water resources, Topics on System Analysis and Integrated Water Resource Management, Castelletti, A. and Soncini-Sessa, R. (eds.), Elsevier, Amsterdam, pp.3-23. (2007)

12. A Castelletti,, Cellina, F. Soncini-Sessa, R. and Weber, E. Comprehensive testing and application of the PIP procedure: the Verbano Project case study, Topics on system analysis and integrated water resources management, Casteletti, A. and Soncini-Sessa, R. (eds.), Elsevier, Amsterdam, pp.223-241, (2007)

13. J.L De Kok, Kofalk, S., Berlekamp, J., Hahn, B. and Wind, H., From design to application of a decision-support system for integrated river basin management, Water Resources Management, Vol.23, pp.1781-1811, (2009)

14. R.Denzer, . Generic integration of environmental - decision support systems stateof-the-art, Environmental Modelling \& Software, Vol.20, pp.1217-1223, (2005)

15. J. Dietrich, Schumann, A.H. and Lotov, A.V. (Workflow oriented participatory decision support for integrated river basin planning, Topics on system analysis and integrated water resources management, Casteletti, A. and Soncini-Sessa, R. (eds.), Elsevier, Amsterdam, pp.207-221, (2007)

16. EU Directive $2000 / 60 / \mathrm{EC}$ of the European Parliament and of the Council of 23 October 2000 establishing a framework for Community action in the field of water policy, Official Journal of the European Communities, L327, 22.12.2000, pp.1-73, (2000)
17. A.Fassio,Giupponi, C., Hiderer, R. and Simota, C. A decision support tool for simulating the effects of alter native policies affecting water resources ,an application at the European scale, Journal of Hydrology, Vol.304, pp.462-476, (2005)

18. D.T Ford, and Killen, J.R., PC-based decision support system for Trinity River, Texas, Journal of Water Resources Planning and Management, Vol.121, No.5, pp.375-381, (1995)

19. A.P Geogakakos, . Decision support systems for integrated water resources management with an application to the Nile Basin, Topics on system analysis and integrated water resources management, Casteletti, A. and Soncini-Sessa, R. (eds.), Elsevier, Amsterdam, pp.99$116,(2007)$

20. C Giupponi,. and Sgobbi, A., Decision support systems for water resources management in developing countries: Learning from experiences in Africa, Water, Vol.5 ,pp.798818. (2013)

21. G.A Gorry, . and Morton, M.S.S. (1971): A framework for management information systems, Sloan School Working Paper, pp.510571. (2000)

22. P.Gourbesville, Integrated river basin management, ICT and DSS: Challenges and needs, Physics and Chemistry of the Earch, Vol. 33, pp.312-321, (2008)

23. P.Gourbesville,. ICT for Water Efficiency, Environmental Monitoring, Ekundayo, E.O. (ed.), InTech, pp.411-426. Gourbesville, P., Du, M., Zavattero, E., Ma, Q. and Gaetano, M. (2018): "Decision support system architecture for real-time water management, Advances in Hydroinformatics, SimHydro 2017" Choosing the Right Model in Applied Hydraulics, pp.259272. (2011)

24. E Guvenc, Ozkaraca, O., Cetin, G., Akcay, G. Development of a web-based decision support system for pediatric patiants, International Journal of Computer Applications, Vol.114, No.6, pp.15-20. (2015)

25. Z. X Ito, K., Xu, ., Jinno, K., Kojiri, T. and Kawamura, A. (Decision support system for surface water planning in river basins, Journal of Water Resources Planning and Management, Vol.127, No.4, pp.272-276, (2001)

26. J.W Labadie, MODSIM, Decision support system for integrated river basin management, Watershed Models, pp.569-591,(2006)

27. Y. Liu, Gupta, H., Springer, E. and Wagener, $T$. Linking science with environmental decision making: Experiences from an integrated model approach to supporting sustainable water resources management, Environmental Modeling \& Software, Vol.23, No.7, pp.846858. (2008)

28. Ma, Q. Deterministic Hydrological Modeling for Real-Time Decision Support Systems, Application to the Var Catchment, France, Doctroal Thesis, Polytech'Lab (Polytech Nice- 
Sophia) of University de Côte d'Azur, 240pp. (2018)

29. M.Matthies, Giupponi, C and Ostendorf, B. Environmental decision support systems: Current issues, methods and tools, Environmental Modelling \& Software, Vol.22, pp.123-127. (2007)

30. P.Mikulecky,, Ponce, D. and Toman, M. A knowledge-based decision support system for river basin management, Transactions on Ecology and the Environment, Vol.60, pp.177186. , (2003)

31. D. Nohara,., Tsuboi, A., Hori, T. Long-term reservoir operation using One-month Ensemble Forecast of Precipitation for introduction to a DSS, Proceedings of 33rd IAHR World Congress, Vancouver, pp.4215-4222, (2009)

32. A.Pierleoni,, Camici, S., Brocca, L., Moramarco, T. and Casadei, S.Climate change and decision support systems for water resources management, Procedia Engineering, Vol.70, pp.1324-1333. (2014)

33. A Serrat- Capdevila,., Valdes, J.B., Perez, J.G., Baird, K., Mata, L.J. and Maddock III, T., Modeling climate change impacts - and uncertainty - on the hydrology of a riparian system: the San Pedro Basin (Arizona/Sonora), Journal of Hydrology, Vol.347, pp.48-66 , (2007)

34. UNESCO IWRM Guidelines at River Basin Level - Part 1 Principles, 24pp. from ,http://unesdoc.unesco.org/images/0018/001864 $/ 18$ 1864e.pdf. Zadeh, L.A. (1965) Fuzzy sets, Information and Control, Vol.8, No.3, pp.338353, (2009)

35. Y. Zen,. Cai, Jia, P, Jee, H. "Development of a web-based decision support system for supporting integrated water resources management in Daegu city, South Korea, Expert Systems with Applications", Vol.39, Issue 11, pp.10091-10102. (Received June 13, 2018), (2012) 